\title{
Analysis of Bacterial Leaf Streak Epidemics on Winter Wheat in Louisiana
}

\author{
K. M. Tubajika and J. S. Russin, Department of Plant Pathology and Crop Physiology, and S. A. Harrison, De- \\ partment of Agronomy, Louisiana State University Agricultural Center, Baton Rouge 70803
}

\begin{abstract}
Tubajika, K. M., Russin, J. S., and Harrison, S. A. 1999. Analysis of bacterial leaf streak epidemics on winter wheat in Louisiana. Plant Dis. 83:541-548.

Studies were conducted to characterize spatial and temporal progress of bacterial leaf streak disease (Xanthomonas translucens pv. translucens) on susceptible (Florida 304) and moderately resistant (Terral 101) winter wheat cultivars. Epidemics were initiated with rifampicin-resistant strain 88-14rif of $X$. translucens pv. translucens by establishing point sources of inoculum in plot centers. Incidence of bacterial leaf streak was assessed five times in 1995 and three times in 1996, starting from the first observation of leaf streak symptoms. Rainfall, temperature, and wind speed were significantly related to disease incidence, but relative humidity was not. The Gompertz model gave the best statistical fit for the progression of disease incidence over time. Average rates of disease progress $(k)$ obtained from the regression of bacterial leaf streak incidence against time provided a good method of comparing the cultivars Florida 304 and Terral 101 and were consistent across locations. Bacterial leaf streak disease gradients were best described by the negative exponential model. Bacterial leaf streak incidence decreased with distance from inoculum source for both cultivars. Disease incidence on Terral 101 was near $0 \%$ at $2 \mathrm{~m}$ from the source, and disease incidence close to the source was consistently lower on Terral 101 than on Florida 304 at all growth stages sampled. This was not unexpected because the two cultivars differed in susceptibility. Disease incidence data were more useful than severity data in providing a good estimate of disease spread away from the source.
\end{abstract}

Additional keywords: disease progress curves, epidemiology, Triticum aestivum

Bacterial leaf streak (BLS), caused by Xanthomonas translucens pv. translucens, was first reported in 1919 from wheat (Triticum aestivum) in Indiana (23). Since then, $X$. translucens pv. translucens has been detected in several wheat production areas in the United States and other countries (26). Losses due to the disease usually have been minor, with occasional reports of severe loss in individual fields. Up to $40 \%$ yield loss has been described from sprinkler irrigated fields in Idaho (10).

Occurrence of BLS is sporadic from year to year $(2,9,25)$. Several studies and reports $(11,13,15-17,20)$ have contributed to better understanding of the ecology and the epidemiology of $X$. translucens pv. translucens, but the reasons for the sporadic occurrence of BLS are still poorly understood. For example, little has been reported on spread of BLS under field conditions. Winter wheat cultivars differ in susceptibility to $X$. translucens pv. translucens (12), but the genetic basis of their

Corresponding author: K. M. Tubajika

E-mail:Ktubaj@1suvm.sncc.lsu.edu

Present address of second author: Department of Plant, Soil and General Agriculture, Southern Illinois University, Carbondale 62901.

Accepted for publication 3 March 1999.

Publication no. D-1999-0405-02R

(C) 1999 The American Phytopathological Society resistance is not known. The roles of resistance and various environmental parameters in disease development and spread are not fully understood. Bamberg (2) and Duveiller et al. (9) reported that environment affected BLS occurrence and that disease severity varied among years and locations. However, both studies failed to indicate which weather parameters were closely associated with the occurrence of BLS in the field. Moreover, there has been very little epidemiological research on $X$. translucens pv. translucens on winter wheat. The objective of this research was to characterize the spatial and temporal progress of BLS on a moderately resistant and a susceptible winter wheat cultivar in Louisiana and to elucidate environmental factors involved in epidemiology of this disease. A preliminary report has been published (24).

\section{MATERIALS AND METHODS}

Bacterial strain and inoculum production. Rifampicin-resistant $X$. translucens pv. translucens strain $88-14^{\text {rif }}$ was provided by E. Milus (University of Arkansas) and maintained on silica gel in a freezer at approximately $-20^{\circ} \mathrm{C}$. Before inoculation, silica gel crystals were placed onto Wilbrink's agar (WBC) (7). Bacterial cells were transferred to liquid 523 medium (21) and incubated at $22^{\circ} \mathrm{C}$ for 3 days on an orbital shaker at $200 \mathrm{rpm}$. A suspen-

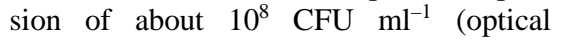
density of 0.10 at $620 \mathrm{~nm}$ ) was used for inoculation. Before transplanting to the greenhouse, seedlings of wheat cultivar Savannah were vernalized in a growth chamber for at least 1 month at 3 to $8^{\circ} \mathrm{C}$ with a photoperiod of $10 \mathrm{~h}$ darkness: $14 \mathrm{~h}$ light. Ten seedlings were transplanted into 7.6-liter plastic pots containing a commercial potting mixture. At transplanting, each pot received $3 \mathrm{~g}$ of 17-6-12 fertilizer. Seedlings were inoculated at Feekes' growth stage (GS) 2 (14) using an artist's airbrush until leaf surfaces were completely wet. Seedlings were incubated at $25^{\circ} \mathrm{C}$ at high humidity for 7 days. Plants were misted with deionized water for $8 \mathrm{~h}$ each night at intervals of $5 \mathrm{~s}$ every $5 \mathrm{~min}$. Pots were watered with tap water to maintain soil moisture each day. Planting date was adjusted to initiate epidemics with diseased seedlings of similar age.

Field plots. Experiments were conducted on a Mhoon silt loam soil at the Ben Hur Research Farm in Baton Rouge and a Gigger silt loam soil at the Northeast Research Station in Winnsboro, Louisiana. Fields at Baton Rouge and Winnsboro were cropped to soybean and sorghum, respectively, the previous year. Plot dimensions were $10.6 \times 10.6 \mathrm{~m}$, with rows spaced $18 \mathrm{~cm}$ apart. A 3-m-wide buffer strip between plots was planted with Florida 401 rye (nonhost) to reduce interplot interference. Crop rows were oriented north-south in Baton Rouge and east-west at Winnsboro. Wheat cultivars Florida 304 (susceptible) and Terral 101 (moderately resistant) were selected based on their reactions to BLS as determined in previous field trials (12). Both cultivars were planted at the seeding rate of $168 \mathrm{~kg} \mathrm{ha}^{-1}$. Ten plots of each cultivar were randomized within each field. The plots were planted on 14 November 1994 and 18 November 1995 in Baton Rouge and on 4 November 1994 and 6 November 1995 in Winnsboro. Stakes were placed $0.18,1,2,4$, and $6 \mathrm{~m}$ away from the center of the plots in four diagonal directions (NE, NW, SE, and SW) for data collection. Two of the 10 plots of each cultivar did not receive point inoculum sources and were used for detection of background contamination and interplot interference.

Epidemics were initiated by establishing a single point source of inoculum in the centers of plots on 3 January 1995 (GS 4) and 12 January 1996 (GS 4) at Baton Rouge and on 5 January 1995 (GS 4) and 11 January 1996 (GS 4) at Winnsboro. One pot containing 10 diseased Savannah seedlings was transplanted to the center of each 
plot. Plots were protected from foliar fungal diseases by applications of propiconazole at $126 \mathrm{~g}$ a.i./ha at GS 6 and 8. Weeds were controlled by using standard chemical and cultural practices.

Disease assessment and data analysis. Incidence of BLS was assessed at various times during the growing season using diagrams developed by Duveiller (8). Disease was estimated on 10 randomly selected plants in each treatment beginning 10 February 1995 and 21 March 1996 at Baton Rouge and 13 February 1995 and 2 April 1996 at Winnsboro. Five BLS assessments were made at 2-week intervals in 1995, but only three were made in 1996 due to a late freeze that caused the death of growing points and subsequent production of new tillers. At each time of sampling, disease was assessed on all leaves of 10 tillers, which were sampled at random on two diagonal transects of each plot. Five leaves from separate tillers at growth stages 4 to 11 were also sampled for $X$. translucens pv. translucens isolation. Leaf samples were bulked and assayed for $X$. translucens pv. translucens strain $88-14^{\text {rif }}$ on Wilbrink's boric acid-cephalexin-rifampicin agar (WBCR).

Individual leaves were surface-sterilized for $30 \mathrm{~s}$ in $1 \% \mathrm{NaOCl}$, rinsed in sterile distilled water, and placed individually in $1.5-\mathrm{ml}$ microcentrifuge tubes containing $0.5 \mathrm{ml}$ of sterile phosphate-buffered saline (6.8 $\mathrm{g}$ of $\mathrm{KH}_{2} \mathrm{PO}_{4}, 1.16 \mathrm{~g}$ of $\mathrm{NaOH}$, and 8.5 $\mathrm{g}$ of $\mathrm{NaCl}$ per liter of distilled water, $\mathrm{pH}$ 7.0). These were shaken for $10 \mathrm{~min}$ and allowed to settle for $2 \mathrm{~min}$. Triplicate platings of serial 10-fold dilutions were made on modified WBCR (7). Plates were incubated at $30^{\circ} \mathrm{C}$ and examined after 4 to 5 days for presence of $X$. translucens $\mathrm{pv}$. translucens. Yellow mucoid colonies char- acteristic of $X$. translucens pv. translucens and similar to the original culture were counted, isolated, and then inoculated to Savannah seedlings in a greenhouse to verify that they were pathogenic $X$. translucens pv. translucens.

Incidence and severity of BLS was assessed on 10 randomly selected tillers from each subplot per plot. Incidence of BLS was expressed as the percentage of the total tillers showing leaf streak symptoms, and BLS severity was expressed as percentage of the total plant leaf area diseased using keys and diagrams developed by Duveiller (8). Final BLS ratings were made at GS 11.1.

Incidence and severity of BLS was analyzed by cultivar and year over time by using disease progress models in order to characterize epidemic development. Incidence and severity of BLS were regressed on time without transformation and after Gompertz $[Y=-\ln (-\ln (y))]$, logistic $[Y=$ $\ln (y / 1-y)], \log$-logistic $[\log (y)=\ln (y / 1-$ $y)]$, monomolecular $[Y=\ln (1 /(1-y))]$, and logarithmic $[Y=\ln (y)]$ transformations. The coefficient of determination, the standard error and significance of the estimated slope parameters, the mean square errors, and the patterns of residuals versus predicted values were used to evaluate the goodness-of-fit of data and to choose the best regression model $(3,18)$.

Similarly, incidence and severity of BLS were regressed on distance without transformation and after $\operatorname{logit}(y)-\log (x)$, $\operatorname{logit}(y)-\operatorname{linear}(x)$, inverse power law $[\log (y)=\log (a)-b \log (x)]$, the negative exponential $[\ln (y)=\ln (a)-b x]$ models, where $y=$ disease incidence or severity, $a=$ intercept, $b=$ slope of disease spread, and $x$ $=$ distance from inoculum source. The half distance $(0.693 / b)$, i.e., the distance at which BLS level was reduced by $50 \%$ from the point source, also was calculated (3).

Temperature, rainfall, and relative humidity were monitored by sensors attached to a datalogger (model CR21, Campbell Scientific, Logan, UT) located in the center of each field. Wind speed and direction were measured at $1.5 \mathrm{~m}$ above the top of the crop with a wind vane and sensitive cup anemometers (Model 104, C. W. Thornthwaite Associates, Logan, UT). These parameters were monitored from 1 November to 30 April during the 1994-95 and 1995-96 growing seasons. Data on rainfall, temperature, relative humidity, and wind speed were summarized using the SUMMARY procedure of Statistical Analysis System (SAS Institute, Cary, NC) to generate average values between sampling times. To determine the relationships of environmental parameters to disease incidence and severity, multiple regression analyses were performed. Incidence and severity of BLS values for each assessment date were regressed on average maximum temperature, minimum temperature, rainfall, wind speed, and relative humidity for each assessment date using the REG procedure of the Statistical Analysis System.

\section{RESULTS}

The 1994-95 growing season was more conducive to BLS development and spread than was the 1995-96 growing season. From inoculation date to 94 to 95 days after inoculation (DAI) (i.e., when final disease incidence data were recorded), 492 and $393 \mathrm{~mm}$ of rainfall were recorded at Baton Rouge and Winnsboro, respectively, in the 1994-95 growing season compared with 329 and $264 \mathrm{~mm}$ recorded for these same locations in the 1995-96 growing

Table 1. Regression analysis of bacterial leaf streak incidence on significantly related environmental parameters at each assessment date at two locations in Louisiana during 1994-95 and 1995-96 growing seasons

\begin{tabular}{|c|c|c|c|c|c|c|c|}
\hline \multirow[b]{2}{*}{ Year } & \multirow[b]{2}{*}{ Location } & \multirow[b]{2}{*}{ DAI $^{\mathbf{b}}$} & \multirow[b]{2}{*}{ Parameters } & \multicolumn{4}{|c|}{ Regression parameters $^{\mathrm{a}}$} \\
\hline & & & & $B_{0}$ & $B_{1}$ & $B_{2}$ & $R^{2}$ \\
\hline \multirow[t]{14}{*}{ 1994-95 } & Baton Rouge & 69 & Minimum temp. (C) & 21.99 & -3.94 & $0.27 *$ & 0.46 \\
\hline & & & Rainfall (mm) & -10.56 & 6.37 & $0.29 * *$ & 0.62 \\
\hline & & & Wind speed $(\mathrm{m} / \mathrm{s})$ & 1.33 & 1.12 & $0.07 * *$ & 0.62 \\
\hline & & 94 & Maximum temp. (C) & 23.94 & -0.645 & $0.02 *$ & 0.54 \\
\hline & & & Minimum temp. (C) & 13.67 & -0.93 & $0.02 * *$ & 0.70 \\
\hline & & & Rainfall (mm) & 16.45 & -0.44 & $0.08 * *$ & 0.69 \\
\hline & & & Wind speed (m/s) & 3.42 & 0.26 & $0.01 * *$ & 0.78 \\
\hline & Winnsboro & 71 & Maximum temp. (C) & 25.75 & -5.67 & $0.93 * *$ & 0.97 \\
\hline & & & Minimum temp. (C) & 13.74 & -1.97 & $0.22 *$ & 0.49 \\
\hline & & & Rainfall (mm) & 34.75 & -23.27 & $3.53 * *$ & 0.74 \\
\hline & & & Wind speed $(\mathrm{m} / \mathrm{s})$ & 7.20 & -2.14 & $0.34 * *$ & 0.57 \\
\hline & & 95 & Minimum temp. (C) & 11.80 & -0.78 & $0.02 * *$ & 0.72 \\
\hline & & & Rainfall (mm) & 0.53 & 3.41 & $0.22 *$ & 0.48 \\
\hline & & & Wind speed (m/s) & 4.80 & $0.12 * *$ & $\ldots$ & 0.64 \\
\hline \multirow[t]{6}{*}{$1995-96$} & Baton Rouge & 94 & Minimum temp. (C) & 11.80 & -0.78 & $0.02 * *$ & 0.70 \\
\hline & & & Rainfall (mm) & 0.53 & 3.41 & $0.12 *$ & 0.54 \\
\hline & Winnsboro & 95 & Maximum temp. (C) & 17.57 & $0.09 * *$ & $\ldots$ & 0.99 \\
\hline & & & Minimum temp. (C) & -2.02 & $0.39 * *$ & $\ldots$ & 0.70 \\
\hline & & & Rainfall (mm) & -60.03 & $4.16^{*}$ & $\ldots$ & 0.48 \\
\hline & & & Wind speed $(\mathrm{m} / \mathrm{s})$ & 3.99 & $0.11 * *$ & $\ldots$ & 0.57 \\
\hline
\end{tabular}

\footnotetext{
a Beta coefficient significant at $P \leq 0.05(*)$ or $P \leq 0.01(* *)$.

${ }^{\mathrm{b}}$ Days after inoculation.
} 
season. Average daily temperature during the same time period at Baton Rouge was $15^{\circ} \mathrm{C}$ in $1994-95$ and $17^{\circ} \mathrm{C}$ in $1995-96$. The average temperature was $13^{\circ} \mathrm{C}$ in $1994-95$ and $15^{\circ} \mathrm{C}$ in $1995-96$ at Winnsboro. However, because of the low temperature during late fall and winter, 1995-96 was cooler than normal, and consequently BLS development was delayed until later in the spring.

Bacteria recovered from diseased plants of both Florida 304 and Terral 101 had colony morphology and antibiotic sensitivity similar to that of the $X$. translucens $\mathrm{pv}$. translucens strain $88-14^{\text {rif }}$ originally used as inoculum. The recovered bacteria consistently caused typical symptoms of bacterial leaf streak on wheat in greenhouse inoculations (data not presented). Symptoms of bacterial leaf streak were not detected on both cultivars grown in the noninoculated check plots that were planted to detect interplot interference (data not presented). Disease incidence data were more useful than severity data in providing a good estimate of disease spread away from the source. Therefore, the incidence data are discussed.
In the results of regression, significant parameter estimates (maximum temperature and minimum temperature) were detected at each assessment date at each location and year. The functional relationship between maximum temperature and minimum temperature was quadratic in most cases. The best fit for the model was accounted for by the linear and quadratic terms. The parameters resulting from the regression of disease incidence on rainfall and wind speed were significant at some assessment dates, locations, and years. The parameters for relative humidity, however, were not significant (Table 1).

Progress of bacterial leaf streak. The response surfaces of untransformed BLS on cultivars Florida 304 and Terral 101 by distance and time are presented in Figures 1 and 2. Bacterial leaf streak symptoms were observed on initially disease-free plants of susceptible Florida 304 in each plot within 38 to 71 days after placement of the focal source plants, but disease development was delayed for 7 to 21 more days on Terral 101. The disease incidence on Florida 304 was greater in 1994-95 than in 1995-96, and this was consistent at Ba- ton Rouge and Winnsboro (Figs. 1 and 2). The incidence of BLS was also greater on Florida 304 than on Terral 101 at Baton Rouge and Winnsboro (Figs. 1 and 2).

At Baton Rouge, the level of BLS incidence recorded on plants at $0.18 \mathrm{~m}$ at the end of growing season was $94 \%$ in 199495 and $40 \%$ in 1995-96. Symptoms of BLS at Baton Rouge were not detected on Florida 304 until 69 DAI in the 1995-96 season (Fig. 1). Symptoms were detected on Terral 101 seven days later, but final disease incidence again was much lower $(38 \%)$ (Fig. 1) than that on Florida 304 (94\%) in 1994-95.

In the 1994-95 growing season, disease symptoms were first observed $38 \mathrm{DAI}$ on susceptible Florida 304 at Baton Rouge but much later (71 DAI) at Winnsboro, which is located further north (Fig. 2). The delay of symptom appearance at Winnsboro resulted in bacterial leaf streak incidence that was $26 \%$ lower than at Baton Rouge at the end of the season. Symptoms on moderately resistant Terral 101 in both years were not detected until nearly 3 weeks after they were observed on Florida 304, and final disease incidence levels on Terral
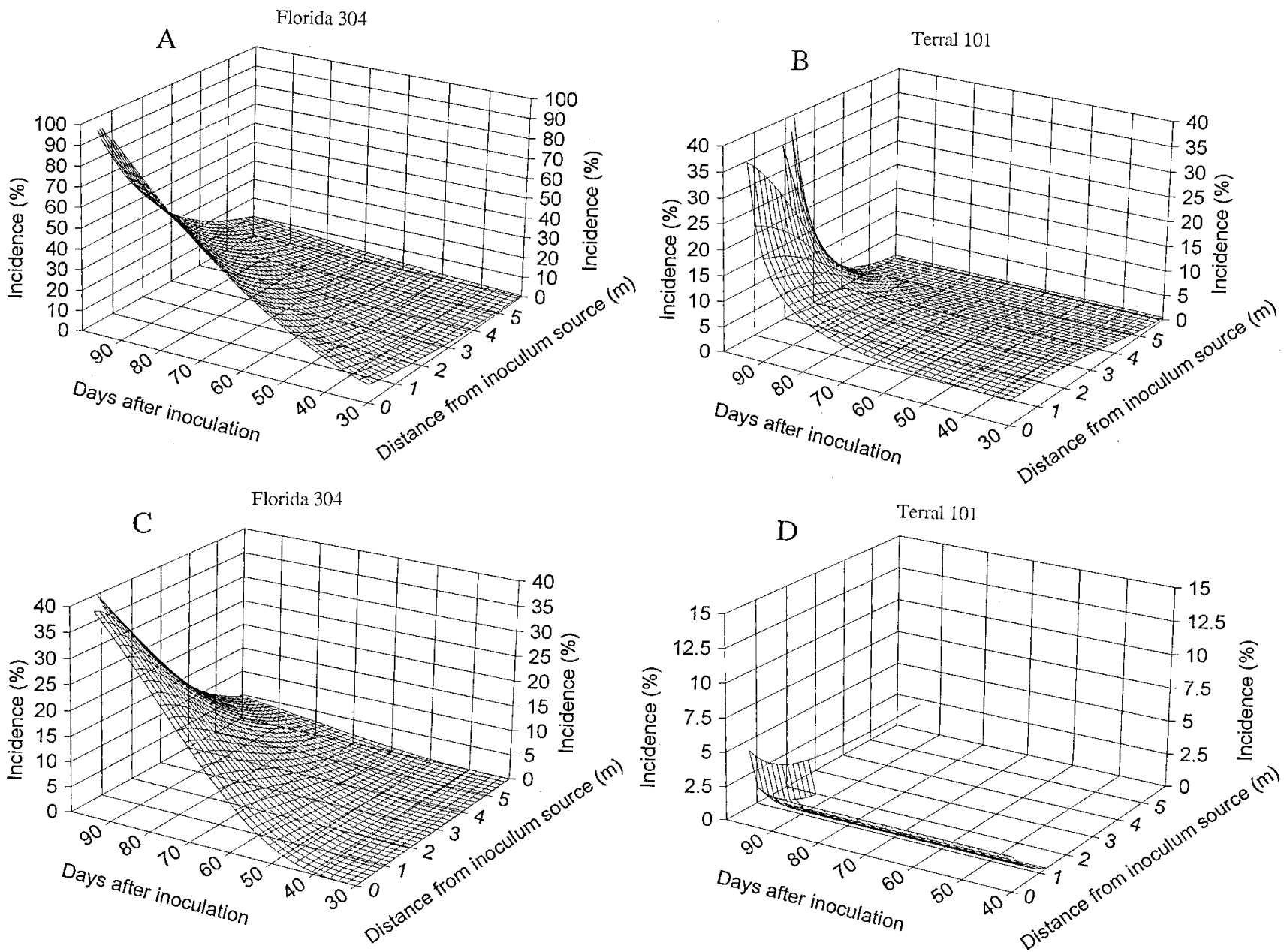

Fig. 1. Incidence of bacterial leaf streak (Xanthomonas translucens pv. translucens) in time and by distance on Florida 304 (A, C) and Terral 101 (B, D) at Baton Rouge during 1994-95 (A, B) and 1995-96 (C, D). Temporal progress and spread were quantified as days after inoculation and distance from a point source, respectively. 
101 were significantly lower than those on Florida 304 at the same distance from the inoculum source in 1994-95 and 1995-96 (Fig. 2).
Based on the significance of $F$ tests, patterns of residual plots, and coefficients of determination $\left(R^{2}\right)$, the disease progress models tested were similar to one another

Table 2. Analysis of variance on the effects of cultivars, sampling direction, time, and dispersal distance of bacterial leaf streak incidence at two locations in Louisiana

\begin{tabular}{|c|c|c|c|}
\hline Source & df & $F$ value & $P>F^{a}$ \\
\hline Cultivar (CV) & 1 & 518.81 & 0.0001 \\
\hline Location (Loc) & 1 & 29.97 & 0.0001 \\
\hline $\mathrm{Loc}^{*} \mathrm{CV}$ & 1 & 0.02 & NS \\
\hline Sampling direction $(\mathrm{SD})^{\mathrm{b}}$ & 3 & 0.66 & NS \\
\hline $\mathrm{SD} * \mathrm{CV}$ & 3 & 2.29 & NS \\
\hline SD*Loc & 3 & 1.24 & NS \\
\hline Time $(T)^{c}$ & 4 & 128.06 & 0.0001 \\
\hline $\mathrm{T}^{*} \mathrm{CV}$ & 4 & 22.25 & 0.0001 \\
\hline $\mathrm{T} * \mathrm{Loc}$ & 4 & 3.98 & 0.0188 \\
\hline $\mathrm{T} * \mathrm{SD}$ & 12 & 0.53 & NS \\
\hline $\mathrm{T} * \mathrm{SD} * \mathrm{CV}$ & 12 & 0.12 & NS \\
\hline $\mathrm{T} *$ Dist & 16 & 14.13 & 0.0001 \\
\hline Distance $(\text { Dist })^{\mathrm{d}}$ & 4 & 59.01 & 0.0001 \\
\hline Dist*CV & 4 & 80.24 & 0.0001 \\
\hline Dist*Loc & 4 & 14.95 & 0.0001 \\
\hline Dist*SD & 12 & 0.62 & NS \\
\hline Dist $^{*} \mathrm{SD} * \mathrm{CV}$ & 12 & 0.39 & NS \\
\hline
\end{tabular}

${ }^{\text {a }}$ Significance at probabilities of $P=0.05$ and greater. NS $=$ nonsignificant values.

${ }^{b}$ Compass direction of north, south, west, and east in which bacterial leaf streak dispersal was quantified.

${ }^{c}$ Refers to sampling time at which disease increase and spread were assessed.

d Distance (m) from inoculum source (infection focus) from which disease was quantified.

in their description of disease increase, but all were less appropriate than the Gompertz model. Therefore, the Gompertz model was used to estimate rates of disease increases $(k)$. Rates of disease increase in susceptible Florida 304 were always significantly greater than those in moderately resistant Terral 101 in both growing seasons (Fig. 3). When the values of BLS incidence were regressed on time (each assessment date) at a particular distance from inoculum source, $k$ ranged from 0.014 to 0.056 for Florida 304 and from 0.008 to 0.029 for Terral 101 (Fig. 3). In both years, $k$ values for Florida 304 were greatest near the point source. Differences in degree of cultivar resistance were also observed at Winnsboro, where rates of disease increase in Florida 304 were always higher than those in Terral 101 (Fig. 4).

Spread of BLS from inoculum source. In both years, neither direction from the inoculum source nor the cultivar by direction interactions significantly affected the slopes of disease gradient or incidence of BLS $(P<0.05)$ on both winter wheat cultivars (Table 2). In the overall analysis, the spread of BLS was affected by cultivar,
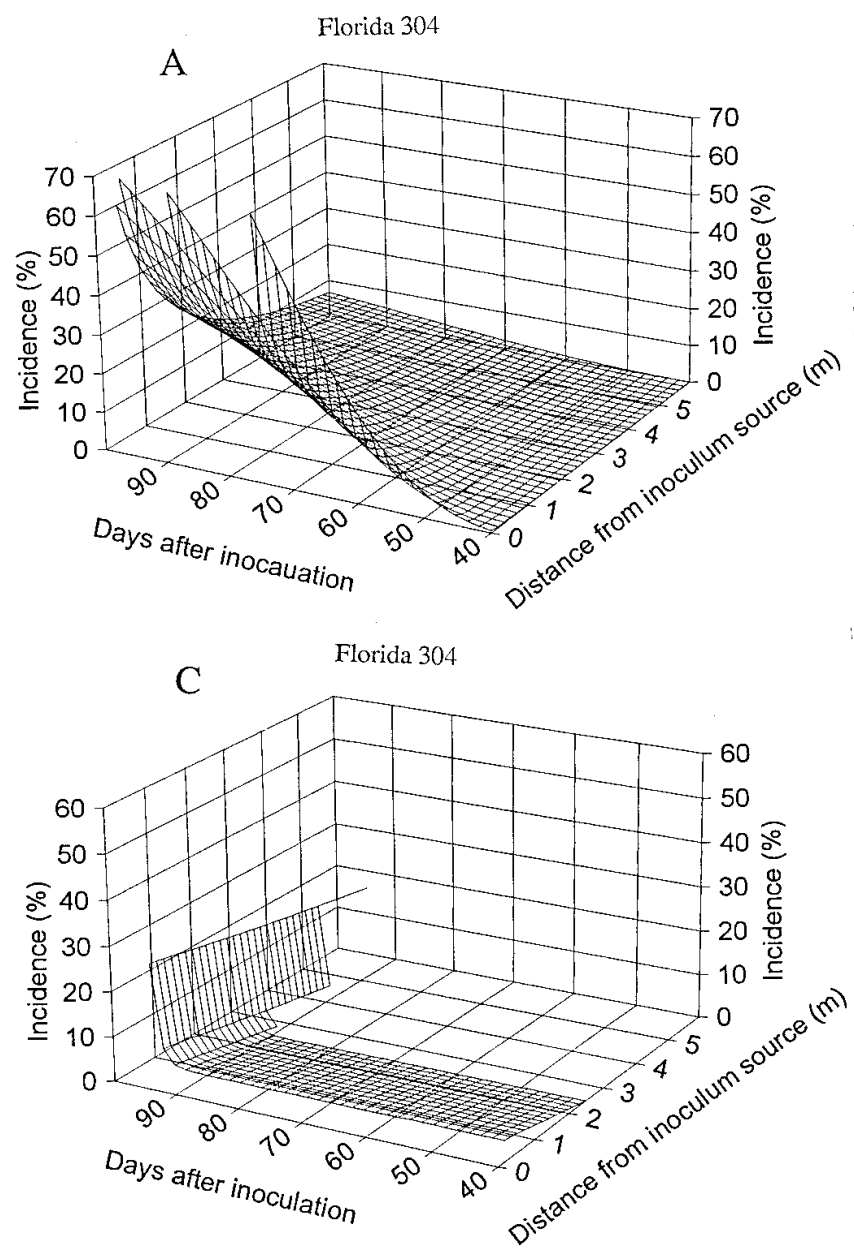

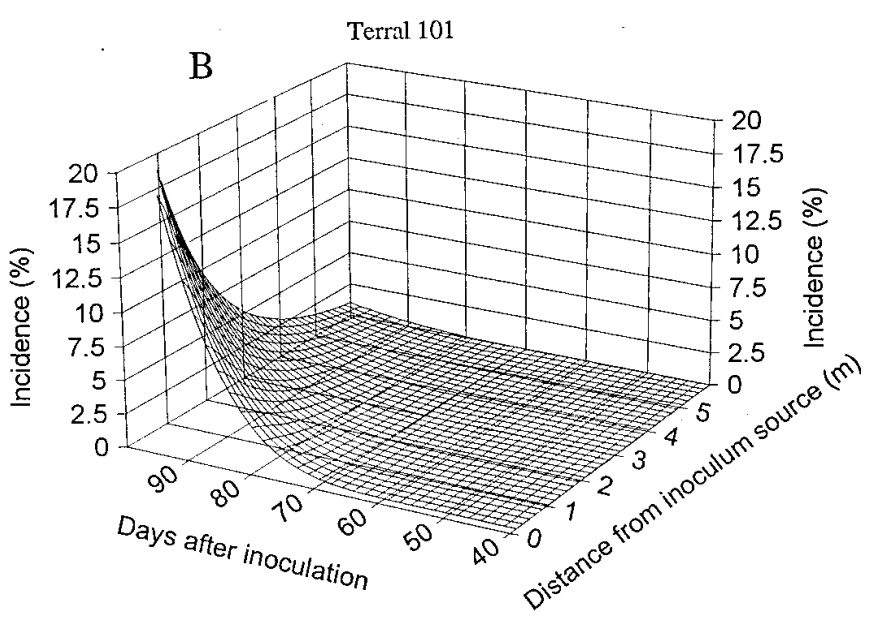

Terral 101

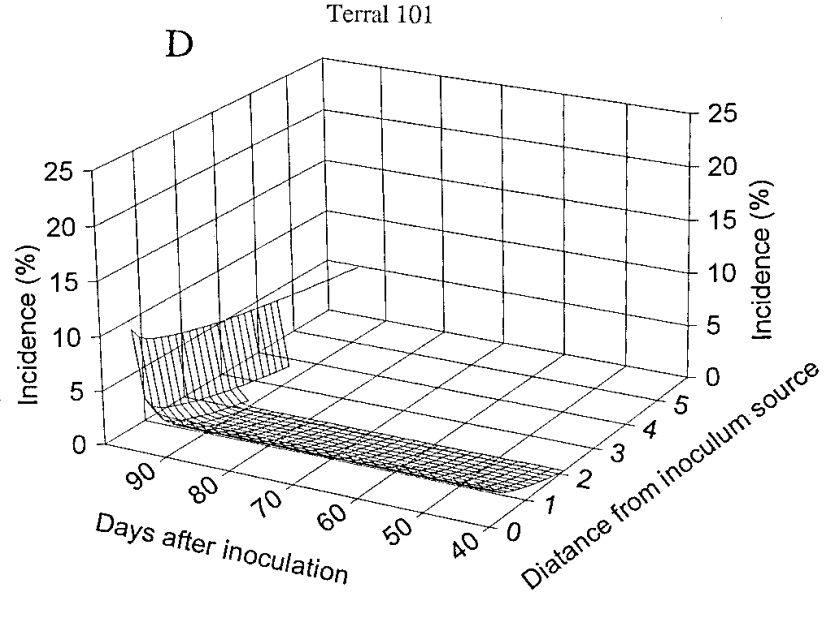

Fig. 2. Incidence of bacterial leaf streak (Xanthomonas translucens pv. translucens) in time and by distance on Florida 304 (A, C) and Terral 101 (B, D) at Winnsboro 1994-95 (A, B) and 1995-96 (C, D). Temporal progress and spread were quantified as days after inoculation and distance from a point source, respectively. 


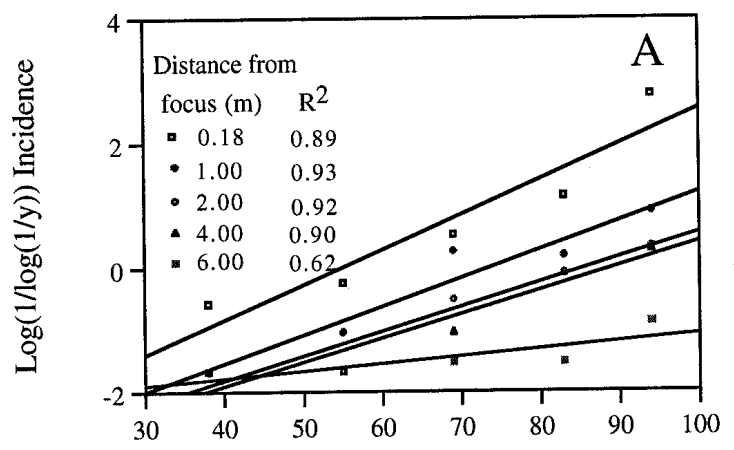

Days after inoculation

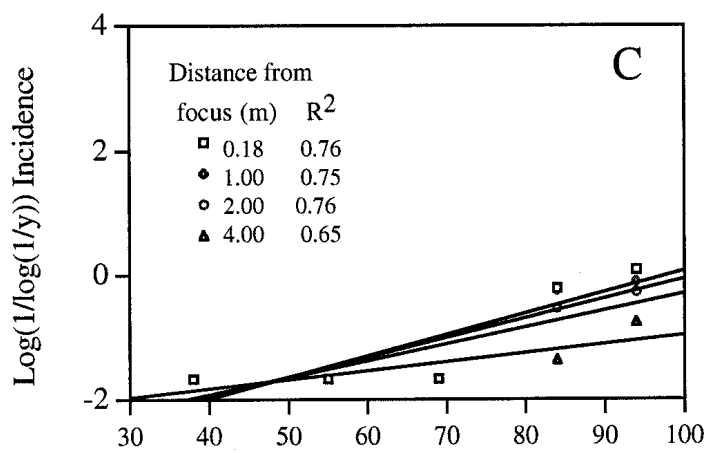

Days after inoculation
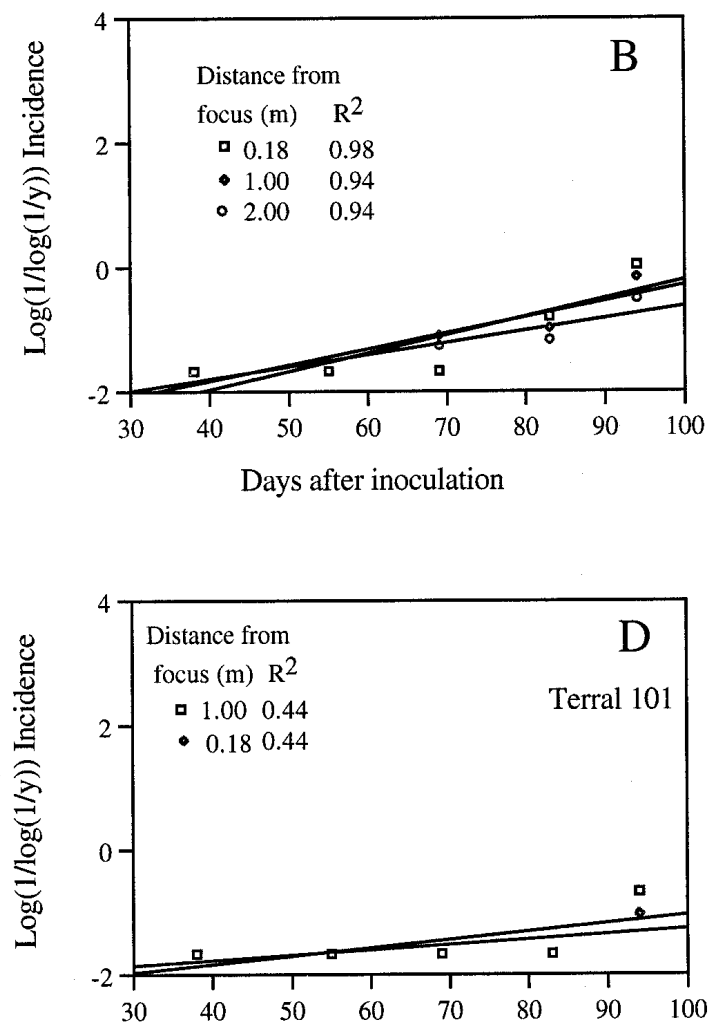

Days after inoculation

Fig. 3. Temporal progress of bacterial leaf streak incidence on Florida 304 (A, C) and Terral 101 (B, D) at Baton Rouge during 1994-95 (A, B) and 199596 (C, D). Temporal progress was quantified using the Gompertz model at each distance from an infection focus.

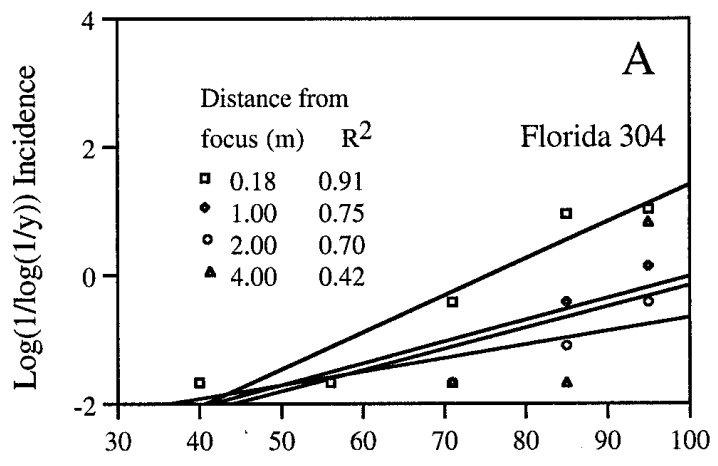

Days after inoculation

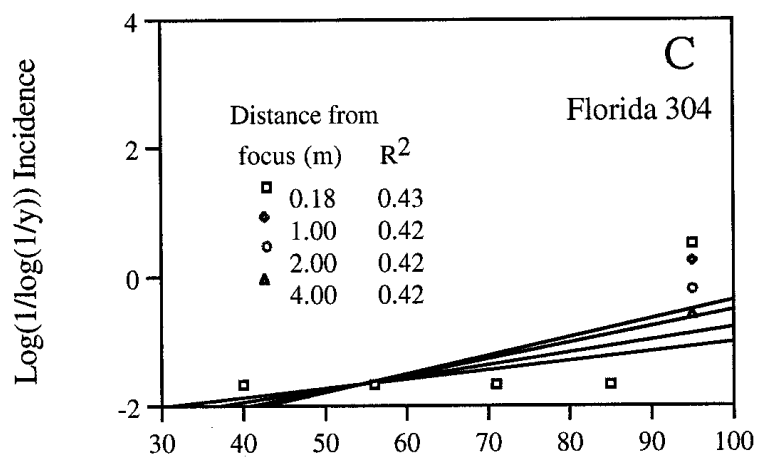

Days after inoculation

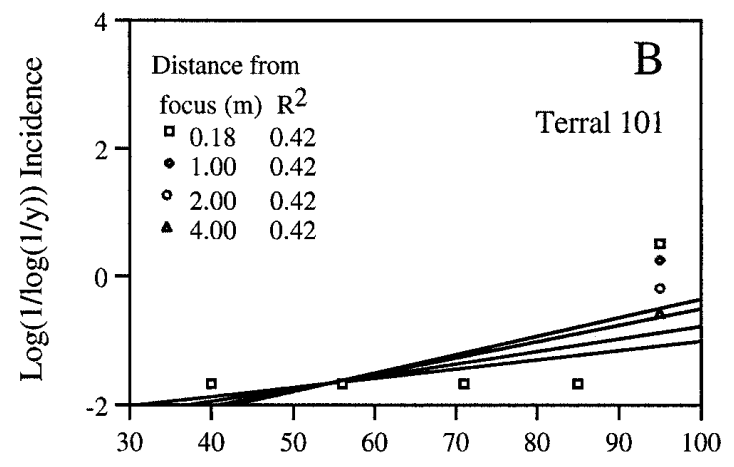

Days after Inoculation

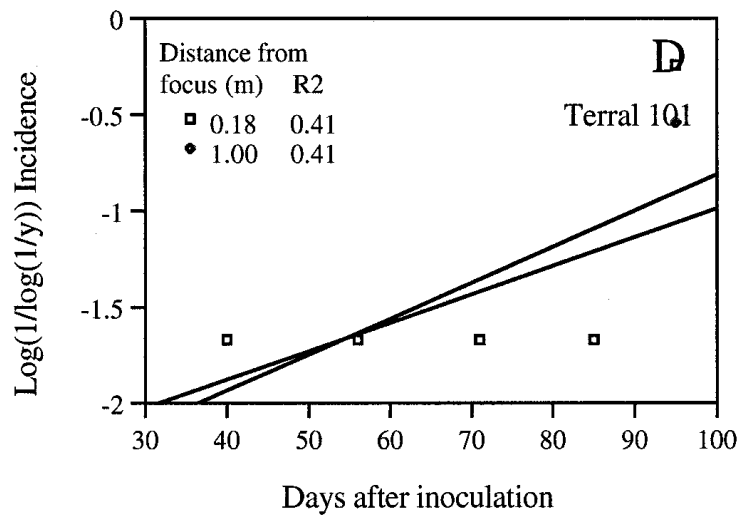

Fig. 4. Temporal progress of bacterial leaf streak incidence on Florida 304 (A, C) and Terral 101 (B, D) at Winnsboro 1994-95 (A, B) and 1995-96 (C, D). Temporal progress was quantified using the Gompertz model at each distance from an infection focus. 

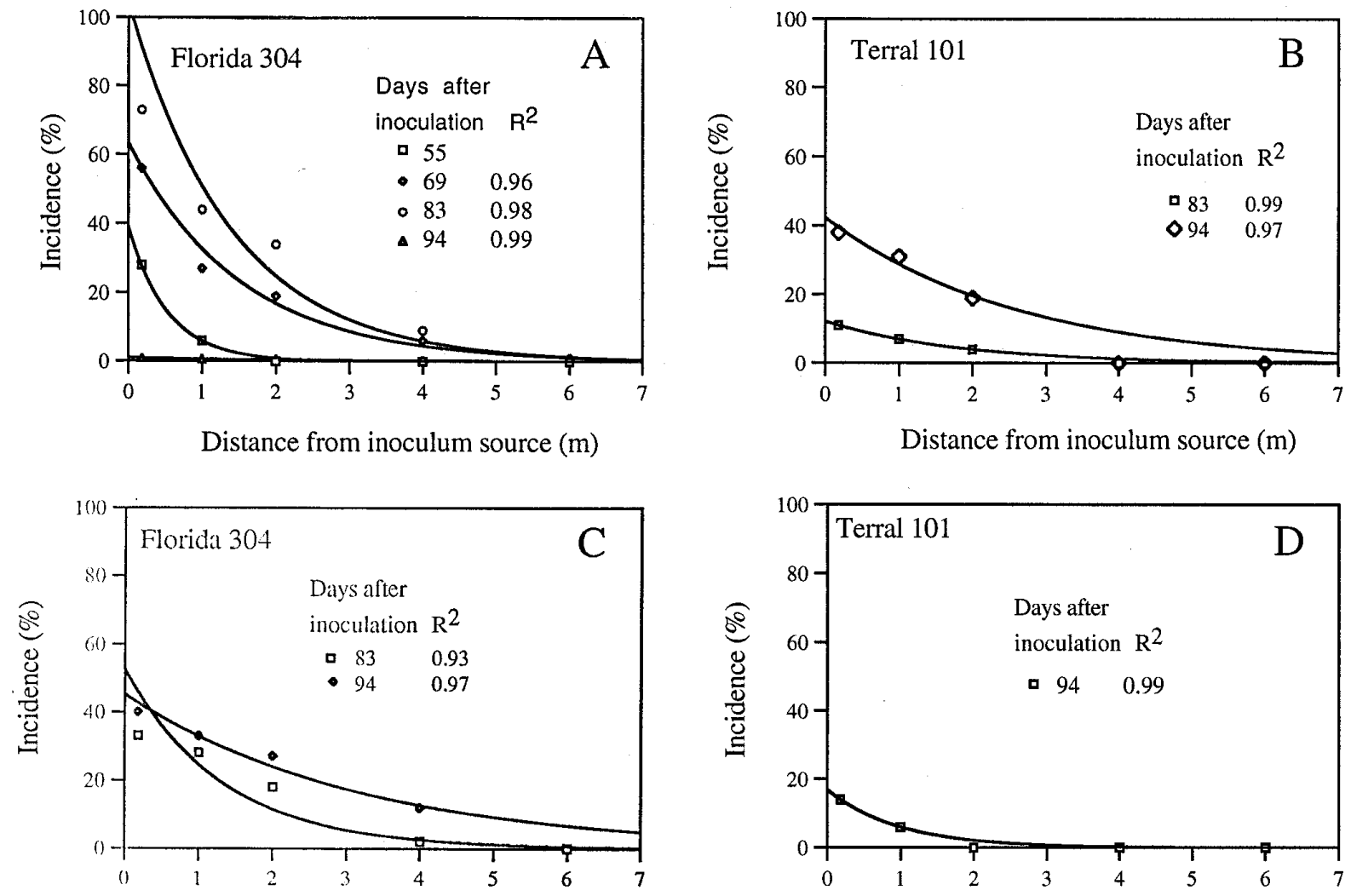

Distance from inoculum source $(\mathrm{m})$

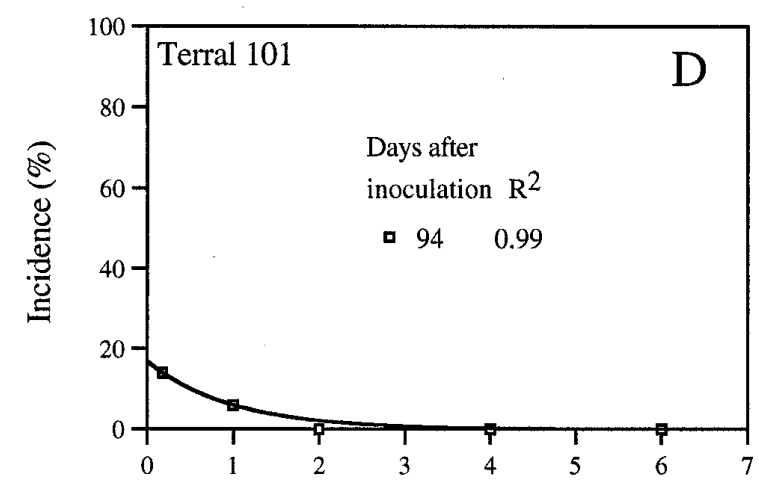

Distance from inoculum source $(\mathrm{m})$

Fig. 5. Spread of bacterial leaf streak incidence on Florida 304 (A, C) and Terral 101 (B, D) at Baton Rouge in 1994-95 (A, B) and $1995-96$ (C, D). Bacterial leaf streak spread was quantified using the negative exponential model by days after inoculation.
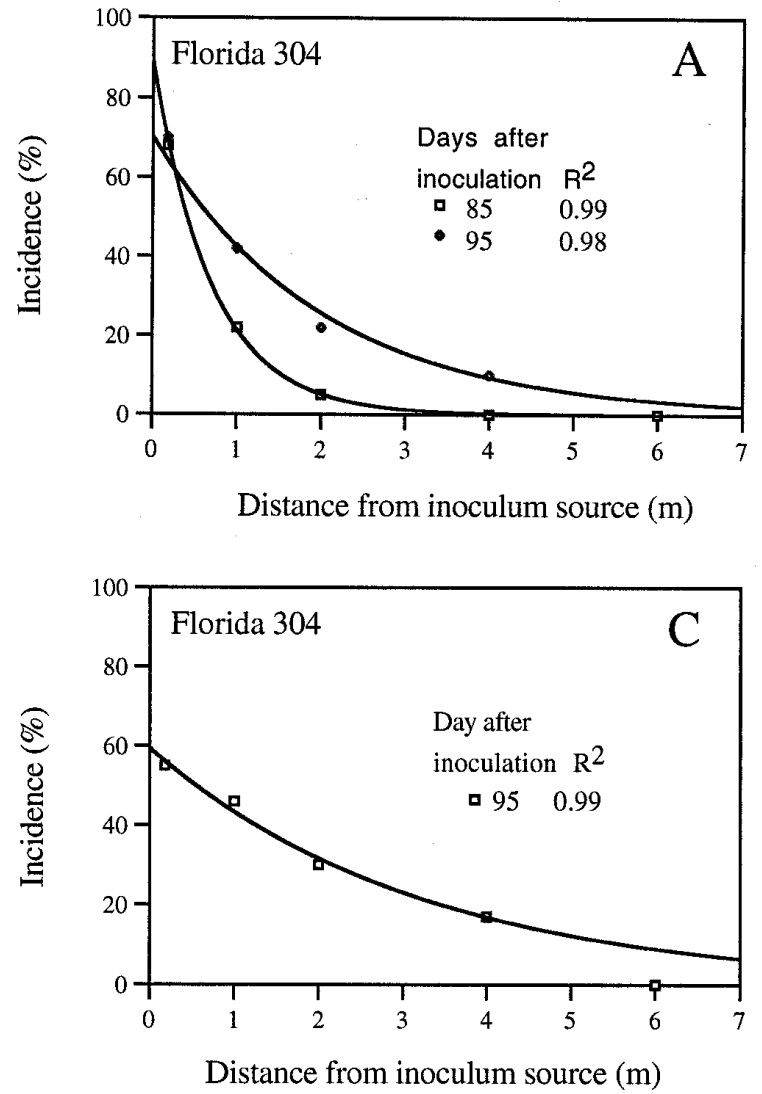

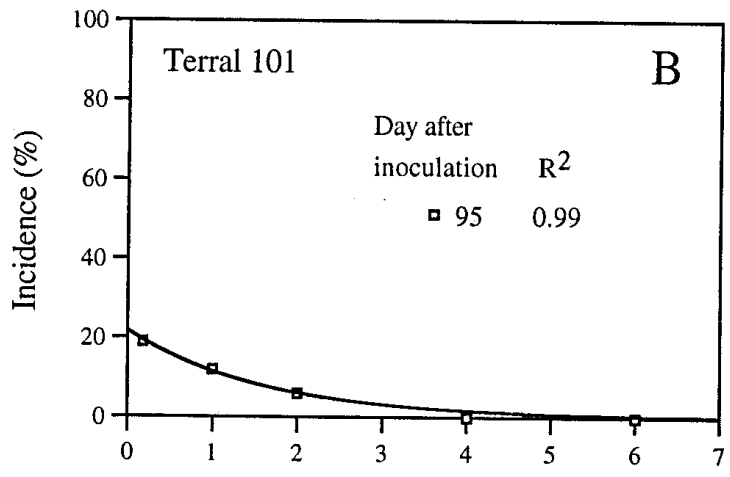

Distance from inoculum source $(\mathrm{m})$

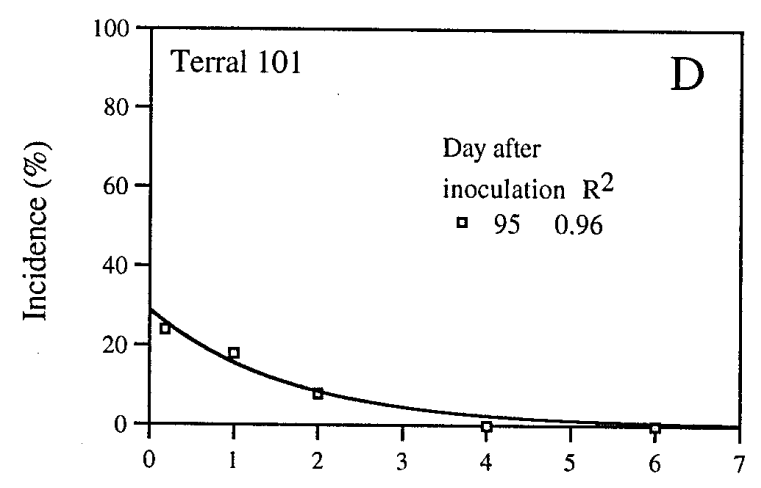

Distance from inoculum source $(m)$

Fig. 6. Spread of bacterial leaf streak incidence on Florida 304 (A, C) and Terral 101 (B, D) at Winnsboro in 1994-95 (A, B) and 1995-96 (C, D). Bacterial leaf streak spread was quantified using the negative exponential model by days after inoculation. 
distance, and sampling time. Symptoms of BLS were not observed in control plots used to test interplot interference.

Disease gradients were best described by the negative exponential model. Incidence of BLS at Baton Rouge decreased with increased distance from the inoculum source in both years. This decrease in BLS incidence was evident at each sampling time and each location (Figs. 5 and 6). The gradients of bacterial leaf streak incidence were steeper for Florida 304 than for Terral 101 (Figs. 5 and 6). Low disease incidence (9\%) was detected on Florida 304 at $6 \mathrm{~m}$ in the 1994-95 season, but incidence of bacterial leaf streak disease on Terral 101 was not detected further than $2 \mathrm{~m}$ from the inoculum source. The analysis of variance data indicated no significant differences in spread by direction on disease incidence; therefore, the parameters of the negative exponential model by sampling direction are not presented. The estimates of the slope parameters $(b)$ were significantly lower for Terral 101 compared with Florida 304 (Figs. 5 and 6). The resulting halfdistances were also greater on Florida 304 than on Terral 101 at Baton Rouge in 199495 and 1995-96 seasons (Table 3). A similar trend was observed at Winnsboro during 1994-95 and 1995-96 seasons (Table $3)$.

\section{DISCUSSION}

This study has shown that wheat plants close to infected plants often were infected extensively with $X$. translucens pv. translucens and provided initial inoculum for disease epidemics. This was indicated by a decrease in BLS incidence with increased distance from point sources, the isolation of marked strain of $X$. translucens pv. translucens from leaf samples, and absence of disease in uninoculated check plots. Therefore, infected plants are capable of spreading disease within wheat fields. Although incidence data were well suited for defining bacterial leaf streak development and spread, monitoring of $X$. translucens pv. translucens over time and space may be more useful in a year where disease symptoms are barely observed.

Cultivar differences were detected using the three-dimensional response surfaces and the estimates of the parameters for disease increase. The Gompertz model has been previously used in describing epidemic development in a number of pathosystems (3). Terral 101 supported low bacterial leaf streak incidence, and disease spread from the point source was delayed. This cultivar had a lower rate of disease increase and a steeper gradient parameter than Florida 304. Since the two cultivars were different in susceptibility to $X$. translucens pv. translucens, this was not unexpected. In both years, most of the leaves of Terral 101 were not infected at distances greater than $2 \mathrm{~m}$ from the point source of inoculum. The mechanism re- sponsible for reduced infection in Terral 101 is unclear, but may be due to a number of internal and external factors that operate to reduce the chance and degree of infection. Waxes on leaf surfaces and a thick cuticle have been implicated in plant defense against the pathogen by preventing the formation of a film of water on which the bacteria might be deposited and multiply (1).

Spread of disease at $6 \mathrm{~m}$ from the source was observed only on the susceptible cultivar, Florida 304, and at one location, Baton Rouge during 1994-95 season. Spread of BLS seemed to be more dependent on susceptibility of the crop than on weather, as shown by the level of resistance exhibited by Terral 101. Previous reports $(5,16,22)$ indicated the spread of BLS to be commonly restricted to distances of 4 to 6 $\mathrm{m}$. These reports did not indicate the reason why the disease was limited to these distances. High disease incidence near the source and lower incidence further from the source was primarily due to allo-infection (depending on dispersal from the point source), but intensification of the disease within the plant was dependent on more limited and local dispersal (auto-infection), as reported elsewhere (19). The reduction in BLS incidence observed in the field was due in part to a late freeze (mid-March) that occurred during the 1995-96 growing season. Most of the tillers were killed, and plants developed secondary tillers.

Daft and Leben (6) reported that the inoculum for bacterial blight caused by Pseudomonas syringae pv. glycinea on soybean was dispersed by rainsplash or wind-driven rain from leaves with diseased lesions to healthy leaves of nearby susceptible plants. They concluded that the aerosols do not remain airborne for long, so the rainsplash can only account for short distance dispersal. Cunfer (4) reported that $X$. translucens pv. translucens is dispersed mainly by rainsplash, although insect transmission and wind-blown aerosols are also important. Overall, the importance of rainfall on spread of the BLS is supported by the significance of the parameter estimates obtained from the regression analysis. However a combination of temperature, wind speed, and rainfall can not be overlooked on the development and spread of this pathogen.

This study showed that winter wheat in Louisiana generally does not exhibit BLS symptoms until onset of reproductive stages in Louisiana. This timing of symptom onset is supported by studies by other authors $(4,9)$. If contaminated seeds are the sole source of primary inoculum, as suggested by several authors $(4,25,26)$, then $X$. translucens pv. translucens must persist as epiphytic populations or latent internal populations for prolonged periods. The levels reached by these epiphytic populations, as well as the factors that induce them to become pathogenic, have not been investigated. Our previous work (25) showed that $X$. translucens pv. translucens can be transmitted to developing seed, where it can persist in the seed and directly impact BLS severity the following season. Infected seed reduce germination and plant

Table 3. Relationship between bacterial leaf streak incidence and distance from the inoculum source for winter wheat cultivars Florida 304 (susceptible) and Terral 101 (moderately resistant)

\begin{tabular}{|c|c|c|c|c|c|}
\hline Location & Year & Cultivar & $\begin{array}{l}\text { Days after } \\
\text { inoculation }\end{array}$ & $\begin{array}{l}\text { Disease gradient } \\
{\text { (slope })^{\mathrm{a}}}^{\text {Dos }}\end{array}$ & $\begin{array}{l}\text { Half distance } \\
\text { (m) }\end{array}$ \\
\hline \multirow[t]{12}{*}{ Baton Rouge } & \multirow[t]{6}{*}{$1994-95$} & \multirow[t]{3}{*}{ Florida 304} & 69 & $0.331 * \mathrm{c}$ & 2.093 \\
\hline & & & 83 & $0.287^{*}$ & $2.448^{*}$ \\
\hline & & & 94 & 0.169 & 4.101 \\
\hline & & \multirow[t]{3}{*}{ Terral 101} & 69 & NS & \\
\hline & & & 83 & 0.241 & 2.875 \\
\hline & & & 94 & 0.167 & 4.150 \\
\hline & \multirow[t]{6}{*}{$1995-96$} & \multirow[t]{3}{*}{ Florida 304} & 69 & NS & \\
\hline & & & 83 & 0.329 & 2.106 \\
\hline & & & 94 & $0.138^{*}$ & $5.021 *$ \\
\hline & & \multirow[t]{3}{*}{ Terral 101} & 69 & NS & \\
\hline & & & 83 & NS & \\
\hline & & & 94 & 0.449 & 1.543 \\
\hline \multirow{11}{*}{ Winnsboro } & \multirow{5}{*}{$1994-95$} & \multirow{2}{*}{ Florida 304} & 85 & 0.624 & 1.110 \\
\hline & & & 95 & $0.220 *$ & $3.150 *$ \\
\hline & & \multirow[t]{3}{*}{ Terral 101} & 71 & NS & \\
\hline & & & 85 & NS & \\
\hline & & & 95 & 0.276 & 2.511 \\
\hline & \multirow[t]{6}{*}{$1995-95$} & \multirow[t]{3}{*}{ Florida 304} & 71 & NS & \\
\hline & & & 85 & NS & \\
\hline & & & 95 & $0.137 *$ & $5.058^{*}$ \\
\hline & & \multirow[t]{3}{*}{ Terral 101} & 71 & NS & \\
\hline & & & 85 & NS & \\
\hline & & & 95 & 0.265 & 2.615 \\
\hline
\end{tabular}

${ }^{a}$ Disease spread was quantified using the negative exponential model.

${ }^{\mathrm{b}}$ Distance at which disease was reduced by $50 \%$.

$\mathrm{c} *=$ slope or half distance significantly different from Terral 101 in the same year at the same location and number of days after inoculation at $P<0.05$. NS $=$ slope not significantly different from zero. 
stand and could provide primary inoculum for disease epidemics. This is a potential problem in Louisiana, where the growers save seed at harvest for use as planting seed. These growers risk stand reductions and possible yield losses in addition to the long-term effect of introducing $X$. translucens pv. translucens inoculum into new fields.

\section{ACKNOWLEDGMENTS}

We thank X. B. Yang and M. Olanya for reviewing this manuscript. This project was supported in part by the Louisiana Soybean and Small Grain Research and Promotion Board. Approved for publication by the Director of the Louisiana Agricultural Experiment Station as manuscript number 98-38-0191.

\section{LITERATURE CITED}

1. Aist, J. R. 1983. Structural responses as resistance mechanisms. Pages 33-68 in: The Dynamics of Host Defense. J. A. Bailey and B. J. Deverall, eds. Academic Press, Orlando, Fl.

2. Bamberg, R. H. 1936. Black chaff disease of wheat. J. Agric. Res. 52:397-417.

3. Campbell, C. L., and Madden, L. V. 1990. Introduction to Plant Disease Epidemiology. John Wiley \& Sons, New York

4. Cunfer, B. M. 1987. Bacterial and fungal blights of foliage and heads of wheat. Pages 528-541 in: Wheat and Wheat Improvement. 2nd ed. E. G. Heynes, ed. ASA, Madison, WI.

5. Cunfer, B. M., Schaad, N. W., and Futral, J. G. 1980. Mechanical device for rapid inoculation with bacterial plant pathogens. Plant Dis. 64:369-371.

6. Daft, G. C., and Leben, C. 1972. Bacterial blight of soybeans: Epidemiology of blight outbreaks. Phytopathology 62:57-62.

7. Duveiller, E. 1990. Seed detection of Xanthomonas campestris pv. undulosa using a modification of Wilbrink's agar medium. Parasitica 40:3-17.

8. Duveiller, E. 1994. A pictorial series of disease assessment keys for bacterial streak of cereals. Plant Dis. 78:137-141.

9. Duveiller, E., Bragard, C., and Maraite, H. 1991. Bacterial diseases in the warmer areasReality or myth? Pages 189-202 in: Proc. Wheat for Nontraditional Warm Areas. Int. Conf., Iguazu Falls. D. Saunders, ed. UNDP/CIMMYT, Mexico.

10. Forster, R. L., and Schaad, N. W. 1988. Control of black chaff of wheat with seed treatment and a foundation seed health program. Plant Dis. 72:935-938.

11. Hall, V. N., Kim, H. K., and Sands, D. C. 1981. Transmission and epidemiology of Xanthomonas translucens. (Abstr.) Phytopathology 71:878.

12. Harrison, S. A., Brown., P. L., Burns, D. R., Caylor, J., Collaku, A., Colyer, P. D., Habetz, R. J., Hallmark, W. B., Lanclos, D., Mascagni, H. J., Moore, S. H., Rabb, J., Rabb, J., Reeder, M. E., Russin, J. S., Seale, C., Shadow, A., Shelton, W., Sistrunk, A., Tubajika, K. M., and Vernon, P. 1996. Performance of small grain varieties in Louisiana, 1995-1996. Louisiana Agricultural Experiment Station Mimeo Series 120

13. Hirano, S. S., and Upper, C. D. 1983. Ecology and epidemiology of foliar bacterial plant pathogens. Annu. Rev. Phytopathol. 21:243269.

14. Large, E. C. 1954. Growth stages in cereals. Illustration of the Feekes Scale. Plant Pathol. 3:128-129.

15. Leben, C. 1965. Epiphytic microorganisms in relation to plant disease, Annu. Rev. Phytopathol. 3:209-230.

16. Mehta, Y. R. 1990. Management of Xantho- monas campestris pv. undulosa and hordei through cereal seed testing. Seed Sci. Technol. 18:467-476.

17. Milus, E. A., and Mirlohi, A. F. 1995. Survival of Xanthomonas campestris pv. translucens between successive wheat crops in $\mathrm{Ar}$ kansas. Plant Dis. 79:263-265.

18. Neter, J., Wasserman, W., and Kutner, M. H 1985. Applied Linear Statistical Models. R. D. Irwin, Inc., Homewood, IL.

19. Robinson, R. A. 1976. Plant Pathosystems. Springer-Verlag, Berlin

20. Sands, D. C., Mizrak, G., Hall, V. N., Kim, H. K., Bockelman, H. E., and Gloden, M. J 1986. Seed transmitted bacterial disease of cereals: Epidemiology and control. Arab. J. Plant Prot. 4:125-127.

21. Schaad, N. W., and Stall, R. E. 1988. Xanthomonas. Pages 81-94 in: Laboratory Guide for Identification of Plant Pathogenic Bacteria. 2nd ed. N. W. Schaad, ed. American Phytopathological Society, St. Paul, MN.

22. Shane, W. W., Baumer, J. S., and Teng, P. S. 1987. Crop losses caused by Xanthomonas streak on spring wheat and barley. Plant Dis. 71:927-930.

23. Smith, E. F., Jones, L. R., and Reddy, C. S. 1919. The black chaff of wheat. Science 50:48.

24. Tubajika, K. M., Russin, J. S., Clark, C. A., and Harrison, S. A. 1996. Spread of Xanthomonas campestris pv. translucens in wheat studied with a rifampicin-resistant strain. (Abstr.) Phytopathology 85:1189.

25. Tubajika, K. M., Tillman, B. L., Russin, J. S., Clark, C. A., and Harrison, S. A. 1998. Relationship between flag leaf symptoms caused by Xanthomonas translucens pv. translucens and subsequent seed transmission in wheat. Plant Dis. 82:1341-1344.

26. Wiese, M. V. 1987. Compendium of Wheat Diseases. 2nd ed. American Phytopathological Society, St. Paul, MN. 